Original Research Paper

\title{
Pengaruh Ekstrak Daun Ketapang (Terminalia cattapa) dan Ragi terhadap Prevalensi dan Intensitas Ektoparasit pada Ikan Karper (Cyprinus carpio)
}

\author{
Dewi Nur'aeni Setyowati $^{1^{*}}$ \& Ni Kadek Puji Astuti ${ }^{1}$ \\ ${ }^{1}$ Jurusan Perikanan dan Ilmu Kelautan, Fakultas Pertanian, Universitas Mataram, Mataram, Indonesia;
}

\section{Riwayat artikel}

Received : 11 September 2019

Revised : 8 April 2020

Accepted : 22 April 2020

Published : 23 April 2020

*Corresponding Author:

Dewi Nur'aeni Setyowati, Jurusan Perikanan dan Ilmu

Kelautan, Fakultas Pertanian Universitas Mataram, Mataram, Indonesia;

Email: dewins@unram.ac.id

\begin{abstract}
Abstrak: Ikan karper merupakan ikan yang penting dalam memberi kontribusi terhadap akuakultur dunia. Salah satu kendala dalam budidaya ikan karper adalah penyakit Tanaman ketapang merupakan tanaman yang dapat berfungsi untuk medis. Penggunaan ragi Saccharomyces cerevisiae dapat meningkatkan sistem imun. Penelitian bertujuan untuk mengetahui pengaruh ekstrak daun ketapang (Terminalia cattapa) dan ragi terhadap prevalensi dan intensitas ektoparasit pada ikan karper (Cyprinus carpio). Penelitian menggunakan metode eksperimental dengan 4 perlakuan yaitu, P1 : daun ketapang $1,2 \mathrm{~g} / \mathrm{L} ; \mathrm{P} 2$ : daun ketapang $1,2 \mathrm{~g} / \mathrm{L}+2,75 \mathrm{~g}$ ragi dalam $16 \mathrm{~L}$ air; $\mathrm{P} 3$ : daun ketapang $1,2 \mathrm{~g} / \mathrm{L}+5,5 \mathrm{~g}$ ragi dalam $16 \mathrm{~L}$ air; dan $\mathrm{P} 4$ : daun ketapang $1,2 \mathrm{~g} / \mathrm{l}+11 \mathrm{~g}$ ragi dalam $16 \mathrm{~L}$ air. Data penelitian dianalisa dengan menggunakan analisa sidik ragam dan analisa regresi linier. Hasil penelitian menunjukkan bahwa penambahan ragi dan bubuk daun ketapang tidak berpengaruh nyata terhadap prevalensi dan intensitas ektoparasit pada ikan karper. Berdasar hasil analisa regresi menunjukkan bahwa penambahan bubuk daun ketapang dan ragi mampu meningkatkan kelangsungan hidup ikan karper.
\end{abstract}

Kata kunci: ikan karper, ketapang, ragi, ektoparasit

Abstract: Carp is an important fish in contributing to world culture. One of the obstacles in carp cultivation is the disease. Cattapa plants can function for medical purposes. The use of yeast can improve the immune system. The study aimed to determine the effect of cattapa leaf extract (Terminalia cattapa) and yeast on the prevalence and intensity of ectoparasites in carp (Cyprinus carpio). The study used an experimental method with 4 treatments, namely, P1: cattapa leaves $1.2 \mathrm{~g} / \mathrm{L}$; P2: cattapa leaves $1.2 \mathrm{~g} / \mathrm{L}+2.75 \mathrm{~g}$ yeast in $16 \mathrm{~L}$ water; P3: cattapa leaves $1.2 \mathrm{~g} / \mathrm{L}+5.5 \mathrm{~g}$ yeast in $16 \mathrm{~L}$ water; and P4: cattapa leaves $1.2 \mathrm{~g} / 1+11 \mathrm{~g}$ of yeast in $16 \mathrm{~L}$ of water. The research data was analyzed using variance analysis and linear regression analysis. The results showed that the addition of yeast and leaf powder of cattapa had no effect on the prevalence and intensity of ectoparasites in carp. Based on the results of the regression analysis, it was found that the filling of cattapa and yeast leaf powder was able to increase the survival of carp.

Keywords: carp, cattapa, yeast, ectoparasite

\section{Pendahuluan}

Ikan karper merupakan ikan yang penting dalam memberi kontribusi terhadap akukultur dunia. Produksi ikan karper $98 \%$ berasal dari Asia (Hartono dan Nasution, 2006). Ikan mas mempunyai toleransi yang tinggi terhadap suhu dan kekeruhan sehingga dapat dibudidaya di sungai, danau, kanal, dan kolam (Khan et al., 2016).

Selain itu, kendala dalam budidaya ikan karper adalah penyakit. Serangan penyakit dapat menyebabkan terjadinya gagal panen produk budidaya sehingga berdampak secara ekonomi pada pembudidaya (Setyowati, 2018). Parasit merupakan penyakit yang sering menyerang ikan. Keberadaan parasit dalam tubuh inang dapat merugikan (Ohoiulun, 2002). Tanaman 
ketapang merupakan tanaman yang dapat berfungsi untuk medis. Daun ketapang digunakan untuk mengurangi $\mathrm{pH}$ dan logam berat di perairan. Daun ketapang juga telah digunakan secara aktif untuk mengurangi parasit dan bakteri (Ololade et al., 2014). Daun ketapang dapat secara signifikan menurunkan jumlah infeksi parasit Dactylogyrus sp. dan Gyrodactylus sp. pada ikan mas koki (Chansue dan Assawaongkasem, 2008).

Hasil penelitian Setyowati (2015) menunjukkan bahwa daun ketapang berdasar hasil analisa regresi menunjukkan dapat mengurangi parasit pada ikan nila. Namun, analisa sidik ragam menunjukkan hasil yang tidak berbeda nyata antara perlakuan perendaman bubuk daun ketapang dengan tanpa perendaman bubuk daun ketapang. Penggunaan ragi Saccharomyces cerevisiae dapat meningkatkan sistem imun (Devoita et al., 2007). Injeksi secara intraperitoneal pada ikan karper mampu meningkatan kelangsungan hidup terhadap serangan Aeromonas hydrophila (Manipo et al., 2015). Penambahan ragi pada perendaman bubuk daun ketapang perlu diteliti untuk mengetahui pengaruhnya terhadap penyakit dan kelangsungan hidup ikan. Oleh karena itu penelitian tentang pengaruh ekstrak daun ketapang (Terminalia cattapa) dan ragi terhadap prevalensi dan intensitas ektoparasit pada ikan karper (Cyprinus carpio) perlu dilakukan.

\section{Bahan dan Metode}

\section{Lokasi dan waktu penelitian}

Penelitian dilaksanakan pada bulan Agustus 2016 sampai Desember 2016 di Laboratorium Program Studi Budidaya Perairan, Universitas Mataram.

\section{Metode penelitian}

Alat yang digunakan pada penelitian ini adalah akuarium, mikroskop, DO meter, oven, alat pengayak, blender, dan grinder. Sedangkan bahan yang digunakan adalah ikan karper, daun ketapang dan ragi. Selanjutnya,

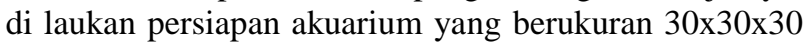
$\mathrm{cm}$ dengan volume air $16 \mathrm{~L}$ (30x30x18 cm) sebagai tempat untuk menampung dan memelihara ikan karper dibersihkan, kemudian diisi air. Ikan karper dimasukkan ke dalam wadah penampungan dan diinkubasi semalam. Selain itu, di lakukan persiapan daun ketapang, daun ketapang yang berwarna coklat dan sudah kering dikurangi kadar airnya dengan menggunakan oven. Setelah itu, daun ketapang dihaluskan dan diayak sampai didapatkan bubuk yang halus.

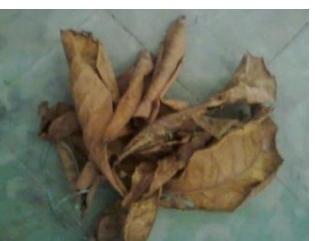

(a)

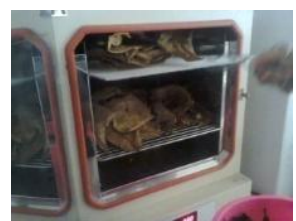

(b)

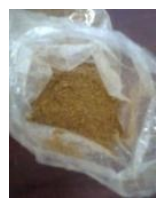

(c)
Gambar 1. Daun Ketapang: (a) Berwarna Coklat, (b) Dioven, (c) Bubuk

Bubuk daun ketapang dilarutkan dengan air panas kemudian diaduk rata dan dibiarkan selama 1 menit agar kandungan dari daun ketapang larut dalam air. Setelah itu, daun ketapang yang telah larut dalam air disaring menggunakan penyaring untuk mengambil ekstrak daun ketapang. Ekstrak daun ketapang yang diperoleh dimasukkan dalam setiap akuarium. Tahapan berikutnya adalah persiapan ragi, dalam hal ini ragi ditumbuk dengan menggunakan grinder sampai halus yang disajikan seperti pada (Gambar 2).

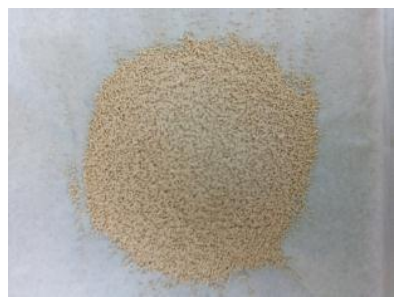

Gambar 2. Ragi yang telah ditumbuk

Tahapan penelitian berikutnya adalah adalah Identifikasi parasit. Dalam hal ini, Identifikasi parasit dilakukan sehari setelah ikan ditampung. Sampel ikan diambil secara acak dan dilakukan pengamatan secara makroskopis dan mikroskopis. Selain identifikasi parasit dilakukan, prevalensi dan intensitas juga dihitung. Tahap berikutnya adalah pengobatan parasit pada ikan karper dengan daun ketapang dan ragi. Ikan karper ditebar ke dalam akuarium dengan jumlah 10 ekor per akuarium (Gambar 3). Bubuk daun ketapang ditambahkan ke dalam air di akuarium dengan berbagai perlakuan:

$\mathrm{P} 1$ : daun ketapang $1,2 \mathrm{~g} / \mathrm{L}$

$\mathrm{P} 2$ : daun ketapang $1,2 \mathrm{~g} / \mathrm{L}+2,75 \mathrm{~g}$ ragi dalam $16 \mathrm{~L}$ air $\mathrm{P} 3$ : daun ketapang $1,2 \mathrm{~g} / \mathrm{L}+5,5 \mathrm{~g}$ ragi dalam $16 \mathrm{~L}$ air $\mathrm{P} 4$ : daun ketapang $1,2 \mathrm{~g} / 1+11 \mathrm{~g}$ ragi dalam $16 \mathrm{~L}$ air Masing-masing perlakuan diulang sebanyak 3 kali. Akuarium yang sudah ditambahkan daun ketapang dan ragi diinkubasi semalam. Selama berlangsunganya penelitian dilakukan pengamatan terhadap kualitas kualitas air yang dilakukan sebelum dan setelah perlakuan. Kualitas air yang diukur meliputi DO, pH, dan suhu. 


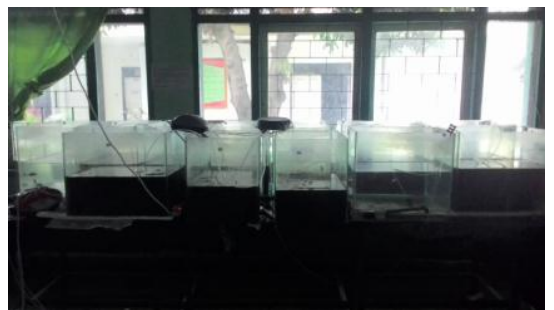

Gambar 3. Proses Perendaman

Analisa Data, tahapan pada analisis data adalah dentifikasi dan perhitungan prevalensi dan intensitas. Ikan karper yang sudah diberi daun ketapang+ragi dan diendapkan semalam diidentifikasi ektoparasitnya. Prevalensi dan intensitas ektoparasit dihitung. Parameter engukuran tingkat kelangsungan hidup. Dalam hal ini, tingkat kelangsungan hidup dihitung dengan menggunakan rumus menurut Effendie (1997):

$S R=\frac{N_{t}}{N_{o}} \times 100 \%$

Keterangan:

SR : Kelangsungan hidup (\%)

No: jumlah ikan pada awal pemeliharaan

$\mathrm{Nt}$ : jumlah ikan pada akhir pemeliharaan

Prevalensi dan Intensitas, Perhitungan prevalensi dan intensitas menurut Novrina (2002) adalah sebagai berikut

$$
\text { Pr evalensi }=\frac{\text { jumlah ikan yang terserang parasit }}{\text { jumlah ikan yang diperiksa }} \times 100 \%
$$

$$
\text { Intensitas }=\frac{\text { jumlah parasit y ang ditemukan }}{\text { jumlah ikan y ang terinfeksi }}
$$

Analysis of Varience (Anova)/analisa sidik ragam dilakukan untuk melihat perbedaaan hasil perlakuan pada taraf kepercayaan $5 \%$ dan dilanjutkan dengan dengan uji BNT pada taraf 5\%. Selain itu, analisa regresi dilakukan untuk melihat kecenderungan pola data yang dihasilkan.

\section{Hasil dan Pembahasan}

\section{Hasil}

\section{Rerata Prevalensi Ektoparasit pada Ikan Karper}

Prevalensi rerata ektoparasit sesudah perlakuan penambahan daun ketapang dan ragi menunjukkan terjadi penurunan prevalensi ikan karper yang terserang parasite (Tabel 1). Pada P1 terjadi penurunan prevalensi ikan karper yang terserang parasit hingga $16,7 \%$. Sedangkan pada perlakuan P2 setelah penambahan daun ketapang dan ragi semua ikan tidak ada yang terserang parasit (prevalensi 0\%). Sedangkan pada P3 prevalensi mencapai 33,3\%. Pada perlakuan P4 ternyata tidak terjadi penurunan prevalensi ikan yang terserang parasit (prevalensi 50\%). Namun demikian, keempat perlakuan setelah diuji anova menunjukkan tidak berbeda nyata antar perlakuan.

Tabel 1. Rerata Prevalensi Ektoparasit

\begin{tabular}{|l|l|l|}
\hline \multirow{2}{*}{ Perlakuan } & \multicolumn{2}{|c|}{ Rerata Prevalensi (\%) } \\
\cline { 2 - 3 } & \multicolumn{1}{|c|}{ Sebelum } & \multicolumn{1}{c|}{ Sesudah } \\
\hline P1 & $50,0^{\text {ns }}$ & $16,7^{\text {ns }}$ \\
\hline P2 & $50,0^{\text {ns }}$ & $0,0^{\text {ns }}$ \\
\hline P3 & $50,0^{\text {ns }}$ & $33,3^{\text {ns }}$ \\
\hline P4 & $50,0^{\text {ns }}$ & $50^{\text {ns }}$ \\
\hline
\end{tabular}

Keterangan $: \mathrm{ns}=$ non signifikan/tidak berbeda nyata.

\section{Intensitas Ektoparasit pada Ikan Karper}

Parasit yang ditemukan pada pengamatan meliputi Dactylogyrus sp., Trichodina sp., Piscicola sp., Gyrodactylus sp., dan Argulus sp. Setelah perlakuan penambahan daun ketapang dan ragi menunjukkan pola yang berbeda antar keempat perlakuan (Tabel 2). Pada perlakuan P1 dan P2 tidak ditemukan parasit setelah perlakuan. Pada perlakuan P3 diperoleh Dactylogyrus sp., Trichodina sp., Piscicola sp., Gyrodactylus sp.. Sedangkan pada perlakuan P4 ditemukan Pisciola sp., Gyrodactylus sp., dan Argulus sp.

Tabel 2. Intensitas Dactylogyrus sp. pada Ikan Karper

\begin{tabular}{|l|l|l|}
\hline Perlakuan & Sebelum & Sesudah \\
\hline P1 & $1,3^{\text {ns }}$ & $0^{\text {ns }}$ \\
\hline P2 & $2^{\text {ns }}$ & $0^{\text {ns }}$ \\
\hline P3 & $1^{\text {ns }}$ & $1^{\text {ns }}$ \\
\hline P4 & $1,7^{\text {ns }}$ & $0^{\text {ns }}$ \\
\hline
\end{tabular}

Keterangan $: \mathrm{ns}=$ non signifikan/tidak berbeda nyata

Parasit Dactylogyrus sp. ditemukan pada semua perlakuan. Intensitas Dactylogyrus tertinggi ditemukan pada P2. Setelah perlakuan, masih ditemukan Dactylogyrus pada P3 (Tabel 3). Namun analisa sidik ragam menunjukkan tidak berbeda nyata antar perlakuan. 
Tabel 3. Intensitas Trichodina sp. pada Ikan Karper

\begin{tabular}{|l|l|l|}
\hline Perlakuan & Sebelum & Sesudah \\
\hline P1 & $1^{\text {ns }}$ & $0^{\text {ns }}$ \\
\hline P2 & $1,5^{\text {ns }}$ & $0^{\text {ns }}$ \\
\hline P3 & $2,3^{\text {ns }}$ & $0^{\text {ns }}$ \\
\hline P4 & $0,7^{\text {ns }}$ & $0^{\text {ns }}$ \\
\hline
\end{tabular}

Keterangan $: \mathrm{ns}=$ non signifikan/tidak berbeda nyata

Trichodina sp. ditemukan pada semua perlakuan. Namun, setelah dilakukan penambahan daun ketapang dan ragi tidak ditemukan Trichodina lagi pada semua perlakuan (Tabel 4). Analisa sisik ragam menunjukkan hasil yang tidak berbeda nyata antar prlakuan.

Tabel 4. Intensitas Piscicola sp. pada Ikan Karper

\begin{tabular}{|l|l|l|}
\hline Perlakuan & Sebelum & Sesudah \\
\hline P1 & $0^{\text {ns }}$ & $0^{\text {ns }}$ \\
\hline P2 & $0^{\text {ns }}$ & $0^{\text {ns }}$ \\
\hline P3 & $0,3^{\text {ns }}$ & $0,7^{\text {ns }}$ \\
\hline P4 & $0^{\text {ns }}$ & $0,3^{\text {ns }}$ \\
\hline
\end{tabular}

Keterangan $: \mathrm{ns}=$ non signifikan/tidak berbeda nyata

Parasit Piscicola sp. ditemukan hanya pada perlakuan P3 dan P4 dan pada perlakuan P1 dan P2 tidak ditemukan parasit tersebut (Table 5). Setelah penambahan daun ketapang dan ragi terjadi peningkatan intensitas Piscicola sp. pada perlakuan P3 dan P4. Namun, hasil analisa sidik ragam menunjukkan tidak berbeda nyata antar perlakuan. Artinya intensitas Piscicola sp. pada perlakuan P3 dan P4 tidak berbeda nyata dengan $\mathrm{P} 1$ dan $\mathrm{P} 2$ yang tidak ditemukan parasit Piscicola sp.

Tabel 5. Intensitas Gyrodactyus sp. pada Ikan Karper

\begin{tabular}{|l|l|l|}
\hline Perlakuan & Sebelum & Sesudah \\
\hline P1 & $0^{\text {ns }}$ & $0^{\text {ns }}$ \\
\hline P2 & $0^{\text {ns }}$ & $0^{\text {ns }}$ \\
\hline P3 & $0^{\text {ns }}$ & $0,3^{\text {ns }}$ \\
\hline P4 & $0,3^{\text {ns }}$ & $0,3^{\text {ns }}$ \\
\hline
\end{tabular}

Keterangan $: \mathrm{ns}=$ non signifikan/tidak berbeda nyata

Pada perlakuan P1, P2 dan P3 tidak ditemukan parasit Gyrodactylus sp. sebelum perlakuan penambahan daun ketapang dan ragi (Tabel 6). Sedangkan pada perlakuan P4 ditemukan parasit Gyrodactylus sp. dengan intensitas yang sama baik sbelum maupun sesudah penambahan daun ketapang dan ragi. Pada perlakuan P3, setelah ditambahkan daun ketapang dan ragi ditemukan parasite Gyrodactylus sp. Namun analisa sidik ragam menunjukkan tidak berbeda nyata antar perlakuan.
Parasit Argulus sp. hanya ditemukan pada perlakuan P4 setelah oenambahan daun ketapang dan ragi. Namun analisa sidik ragam menunjukkan tidak berbeda nyata antar perlakuan.

Tabel 6. Intensitas Argulus sp. pada Ikan Karper

\begin{tabular}{|l|l|l|}
\hline Perlakuan & Sebelum & Sesudah \\
\hline P1 & $0^{\text {ns }}$ & $0^{\text {ns }}$ \\
\hline P2 & $0^{\text {ns }}$ & $0^{\text {ns }}$ \\
\hline P3 & $0^{\text {ns }}$ & $0^{\text {ns }}$ \\
\hline P4 & $0^{\text {ns }}$ & $0,3^{\text {ns }}$ \\
\hline
\end{tabular}

Keterangan $: \mathrm{ns}=$ non signifikan/tidak berbeda nyata

\section{Kelangsungan Hidup Ikan Karper}

Hasil analisa anova untuk kelangsungan hidup ikan karper pada (Tabel 7) menunjukkan tidak berbeda nyata antar perlakuan. Kelangsungan hidup tertinggi terdapat pada perlakuan P4 sebesar 96,7\%. Sedangkan kelangsungan hidup terendah diperoleh pada perlakuan P2 sebesar 56,7\%. Hasil analisa regresi pada gambar 3 menunjukkan nilai $\mathrm{R}^{2}$ sebesar 0,6914 dan hasil analisis regresi kelangsungan hidup ikan karper seperti yang disajikan pada (Gambar 4).

Tabel 7. Kelangsungan Hidup (\%) Ikan Karper

\begin{tabular}{|l|l|}
\hline \multicolumn{1}{|c|}{ Perlakuan } & \multicolumn{1}{|c|}{ Kelangsungan Hidup (\%) } \\
\hline P1 & $66,7^{\text {ns }}$ \\
\hline P2 & $56,7^{\text {ns }}$ \\
\hline P3 & $76,7^{\text {ns }}$ \\
\hline P4 & $96,7^{\text {ns }}$ \\
\hline
\end{tabular}

Keterangan : ns = non signifikan/tidak berbeda nyata

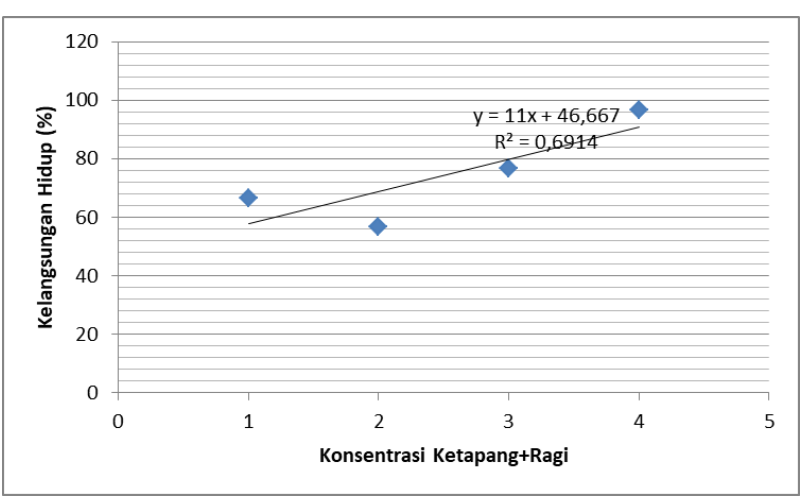

Gambar 4. Analisa Regresi Linier Daun Ketapang + ragi (x) dan Kelangsungan Hidup (y) setelah penambahan daun ketapang + ragi

\section{Kualitas Air}

Hasil analisa kualitas air yang meliputi parameter DO, suhu dan $\mathrm{pH}$ terhadap semua perlakuan seperti pada (Tabel 8). Nilai parameter, seperti DO menunjukkan 
nilai yang rendah pada perlakuan P2 (3,2 ppm) dan P3 (2 ppm). Selanjutnya, parameter suhu menunjukkan nilai suhu sebesar $29-30^{\circ} \mathrm{C}$. Sementara itu, nilai $\mathrm{pH}$ berada pada kondisi normal antara 6,7-7,2 terhadap semua perlakuan dari penelitian ini.

Tabel 8. Hasil Analisa Kualitas Air

\begin{tabular}{lllll}
\hline $\begin{array}{l}\text { Kualitas } \\
\text { Air }\end{array}$ & P1 & P2 & P3 & P4 \\
\hline DO (ppm) & $3,2-6,7$ & $5,1-5,2$ & $2-6$ & $4,3-4,7$ \\
Suhu $\left({ }^{0} \mathrm{C}\right)$ & 30 & 30 & 29 & 29 \\
pH & $6,8-6,9$ & $6,7-6,9$ & $6,8-7,0$ & $6,9-7,2$ \\
\hline
\end{tabular}

\section{Pembahasan}

\section{Rerata Prevalensi Ektoparasit pada Ikan Karper}

Hasil penelitian di tabel 1 menunjukkan bahwa prevalensi ikan yang terserang parasit mengalami penurunan pada perlakuan penambahan daun ketapang dan ragi. Namun, hasil analisa sidik ragam menunjukkan bahwa tidak ada perbedaan yang nyata antar perlakuan. Hal tersebut menunjukkan bahwa penambahan daun ketapang dan ragi tidak memberikan pengaruh dalam mengurangi parasit pada ikan karper. Hasil penelitian Mbengui et al. (2013) menunjukkan bahwa ekstraksi daun ketapang dengan pelarut methanol dan etanol memberikan hasil yang lebih baik dibandingkan dengan pelarut air biasa. Nadirah et al. (2013) juga menyebutkan bahwa ekstraksi dengan ethanol pada daun ketapang tua memperlihatkan antibakterial yang lebih besar dibanding ekstraksi menggunakan air. Penelitian ini menggunakan pelarut air biasa sehingga kemungkinan membuat penambahan daun ketapang kurang efektif untuk mengurangi prevalensi ikan karper yang terserang parasit.

\section{Rerata Intensitas Ektoparasit pada Ikan Karper}

Rerata intensitas ektoparasit setelah perendaman bubuk daun ketapang dan ragi menunjukkan hasil yang tidak berbeda nyata (tabel 2, 3, 4, 5, dan 6). Ragi dari Saccharomyce scerevisiae mengandung polisakarida berupa glukan. Ragi mampu meningkatkan pertahanan tubuh non spesifik pada ikan dan kerang-kerangan (Mastan, 2015)..

Pada perlakuan ditemukan parasit Dactylogyrus sp, Trichodina sp., Piscicola sp., Gyrodactylus sp., dan Argulus sp. Dactylogyrus merupakan parasit yang menyerang insang. Parasit ini menyerang ikan Cyprinidae (Benovics et al., 2018).

Trichodina sp. adalah parasit yang termasuk protista. Serangan Trichodina sp. dapat mempengaruhi budidaya ikan dan memberi dampak negtaif secara ekonomi (Wiroonpan dan Purivirojkul, 2019).

Piscicola sp. termasuk ke dalam filum Annelida. Parsit ini melekat di kulit ikan. Infeksi karena Piscicola tidak menyebabkan bahaya yang serius jika cepat ditangani (Meyers et al., 2008).

Gyrodactylus merupakan parasit dari phylum platyhelminthes. Parasit ini mampu menginfeksi bagian sirip, insang dan permukaan tubuh. Ikan yang terkena parasit ini akan berwarna pucat (Kaata, 1985 cit Novrina, 2002).

Argulus disebut juga kutu ikan. Parasit ini menyerang ikan air tawar. Serangan yang berat dari parasit ini dapat menyebabkan kerusakan kulit ikan dan bahkan mampu menyebabkan kematian (Alas et al., 2010).

\section{Kelangsungan Hidup Ikan Karper}

Hasil analisa sidik ragam terhadap kelangsungan hidup ikan karper yang diberi daun ketapang dan ragi menunjukkan tidak berbeda nyata (tabel 7). Namun, hasil analisa regresi menunjukkan pola bahwa penambahan daun ketapang dan ragi mampu meningkatkan kelangsungan hidup ikan karper dengan nilai R2 sebesar $\mathrm{R}^{2}$ sebesar 0,6914\%. (gambar 3). Sembiring (1995) mengatakan bahwa semakin dekat $\mathrm{R}^{2}$ dengan 1 makin baik pula kecocokan data dengan apa yang dipengaruhi (daun ketapang dan ragi), begitu juga sebaliknya jika $\mathrm{R}^{2}$ mendekati 0 maka semakin jelek kecocokan data dengan apa yang dipengaruhi (daun ketapang dan ragi).

Menurut Dugger dan Jory (1999) dalam Hisano et al. (2008), penambahan ragi dalam pakan udang mampu menurunkan kematian udang dari penyakit serta mampu menghindari udang dari stress karena penanganan. Penelitian Abdel-Tawwab et al. (2008) pada ikan nila yang diuji tantang dengan Aeromonas hydrophila juga menunjukkan bahwa kematian ikan setelah diinjeksi intraperitoneal dengan Aeromonas hydrophila mengalami penurunan kematian secara signifikan dengan penambahan suplemen ragi.

\section{Kualitas Air}

Hasil penelitian (tabel 8) menunjukkan bahwa secara umum kisaran kualitas air masih sesuai untuk pemeliharaan ikan karper. Menurut Kartamihardja (1981) dalam Rudiyanti dan Ekasari (2009), DO yang yang optimum untuk pemeliharaan ikan karper adalah lebih dari 3 ppm. Hasil penelitian menunjukkan semua perlakuan memiliki nilai DO lebih dari 3 ppm. Hanya pada perlakuan P3 yang menunjukkan nilai DO sempat mencapai 2 ppm, namun kisaran DO maksimal masih memenuhi syarat untuk pemeliharaan ikan mas yaitu sebesar 6 ppm.

Suhu selama penelitian juga masih memenuhi syarat untuk pemeliharaan ikan karper. Hal tersebut sesuai dengan pendapat Kelabora (2010), bahwa suhu yang optimum untuk pemeliharaan ikan mas sebesar $28^{\circ} \mathrm{C}$ dan tidak berbeda nyata dengan suhu 300C. Hal 
ersebut menunjukkan bahwa suhu dari hasil penelitian $\left(29-30^{\circ} \mathrm{C}\right)$ masih menunjukkan nilai yang optimal

Menurut Pescod (1973) dalam Rudiyanti dan Ekasari (2009), pH yang optimum untuk pemeliharaan ikan karper sebesar 6,5-8,5. Hasil penelitian menunjukkan walaupun ada penambahan daun ketapang yang dapat menurunkan $\mathrm{pH}$ perairan, namun nilai $\mathrm{pH}$ masih dalam batas yang optimum untuk pemeliharaan ikan karper.

\section{Kesimpulan}

Hasil penelitian menunjukkan bahwa penambahan ketapang dan ragi tidak berpengaruh terhadap prevalensi dan intensitas ektoparasit pada ikan karper. Berdasar analisa regresi, penambahan dan ketapang dan ragi menunjukkan kecenderungan meningkatkan kelangsungan hidup ikan karper.

\section{Ucapan Terima Kasih}

Tim peneliti mengucapkan terima kasih kepada Dekan Fakultas Pertanian, khususnya Program Studi Budidaya Perairan yang telah memberikan fasilitas laboratorium untuk pelaksanaan penelitian ini.

\section{Daftar Pustaka}

Alas, A., Oktener, A. \& Solak, K. (2010). A Study on The Morphology of Argulus foliaceus Lin. 1758 (Crustacea: Branchiura) Procured from Cavuscu Lake (Central Anatolia-Turkey) with Scanning Electron Microscopy. Turk J Biol. 34: 147-151. DOI: 10.3906/biy-0811-27 https://www.researchgate.net/publication/228373 882 study on the morphology of Argulus foli aceus_Lin_1758_Crustacea_Branchiura_procured from Cavuscu Lake_Central_Anatolia-

Turkey_with_scanning electron.

Benovics, Desdevises, Y. Vukic, J., Sanda, R. \& Simkova, A. (2018). The phylogenetic relationships and species richness of host-specifc Dactylogyrus parasites shaped by the biogeography of Balkan cyprinids. DOI:10.1038/s41598-018-31382-w

https://hal.sorbonne-universite.fr/hal01870454/document

Effendie (1997). Biologi Perikanan. Yayasan Pustaka Nusatama. Yogyakarta. 163 hal. https://scholar.google.co.id/scholar?hl=id\&as_sdt $=0 \% 2 \mathrm{C} 5 \& \mathrm{q}=$ Biologi + Perikanan $\& b t n G$
Hartono, T. T. \& Nasution, Z. (2006). Status and Constrains of Carp Aquaculture Industry Development in Indonesia. Buletin Ekonomi Perikanan. Vol VI https://scholar.google.co.id/scholar?hl=id\&as_sdt $=0 \% 2 \mathrm{C} 5 \& \mathrm{q}=$ Status + and + Constrains + of + Carp $+\mathrm{A}$ quaculture+Industry+Development+in+Indonesia $\underline{\text { \&btnG}}=$

Hisano, H., Falcon, D. R., barros, M. M. \& Pezzato, L. E. (2008). Influence of Yeast and Yeast Derivatives on Growth Performance and Survival of Juvenile Prawn Macrobrachium amazonicum. Cienca Animal Brasileria. 9 (3): 657-662. https://www.researchgate.net/publication/435306 06_INFLUENCE_OF_YEAST_AND_YEAST_ DERIVATIVES_ON_GROWTH_PERFORMAN CE_AND_SURVIVAL_OF_JUVENILE_PRAW N_Macrobrachium_amazonicum_INFLUENCIA _DA_LEVEDURA_E_DERIVADOS_SOBRE_ O_DESEMPENHO_E_SOBREVIVENCIA_DE_ JUVENIS

Kelabora, D. M. (2010). Pengaruh Suhu terhadap Kelangsungan Hidup dan Pertumbuhan Larva Ikan Mas (Cyprinus carpio). Berkala Perikanan Terubuk. $\quad 38 \quad$ (1): $\quad 71-81$. https://terubuk.ejournal.unri.ac.id/index.php/JT/ar ticle/viewFile/248/242

Khan, M. N., Shahzad, K., Chatta, A., Sohail, M., Piria, M. \& Treer, T. (2016). A Review of Introduction of Common Carp Cyprinus carpio in Pakistan: Origin, Purpose, Impact and Management. Croatian Journal of Fisheries. 74: 71-80. DOI: 10.1515/cjf-2016-0016. https://bib.irb.hr/datoteka/818773.Khan_et_al_20 16 Reviev_carp_Pakistan1.pdf

Manoppo, H., Tumbol, R. A. \& Manurung, U. N. (2015). Incorporation of Baker's Yeast Cells as Immunostimulant in Feed Enhance Resistance of Nile Tilapia Aeromonas hydrophila. International Journal of Pharm Tech Research. (5): 797-802. http://sphinxsai.com/2015/ph_vol8_no5/1/(797802)V8N5PT.pdf

Mastan, S. A. (2015). Use of Immunostimulants in Aquaculture Disease Management. International Journal of Fisheries and Aquatic Studies. 2(4): 277-280.

http://www.fisheriesjournal.com/vol2issue4/Pdf/2 -4-59.1.pdf 
Mbengui, R. D., Guessnnd, N. K., M'Boh, G. M., Golly, J. K., Okou, C. O., Nguessan J, D., Dosso, M. \& Djaman, J. A. (2013). Phytochemical Screening and Study of Comparative Antibacterial Activity of Aqueous and Alcoholic Extracts of The Leaves and Barks of Terminalia catappa on Multiresistan Strains. Journal of Applied Biosciences: 50405048.

https://pdfs.semanticscholar.org/8469/122a93b4d $\underline{8 \text { a899feac3a1dfcb784ea14eecb.pdf? ga }=2.17100}$ 6944.151124998.1587559979$\underline{262561278.1587559979}$

Meyers, T., Burton, T., Bentz, C. \& Starkey, N. (2008). Common Diseases of Wild and Cultured Fishes in Alaska. Alaska Department of Fish and Game. Fish Pathology Laboratories. 112p. https://scholar.google.co.id/scholar?hl=id\&as_sdt $=0 \% 2 \mathrm{C} 5 \& \mathrm{q}=$ Common + Diseases + of + Wild + and + Cultured+Fishes+in+Alaska.+\&btnG

Nadirah, M., Wee, T. L. \& Najiah, M. (2013). Differential Responses of Vibrio sp. to Young and Mature Leves Extracts of Terminalia catappa L. International Food Research Journal. 20(2): 961-966. http://www.ifrj.upm.edu.my/volume-202013.html

Nantarika, C. \& Assawawongkasem, N. (2008). The in Vitro Antibacterial Activity and Ornamental Fish Toxicity of The Water Extract of Indian Almond Leaves (Terminalia catappa Linn.). KKU Vet J (18) 1: 36-45. https://www.researchgate.net/publication/238103 693 The in vitro_Antibacterial_Activity and $\mathrm{O}$ rnamental Fish Toxicity of the Water Extract of Indian Almond Leaves Terminalia catappa $\underline{\text { Linn }}$

Novrina (2002). Inventarisasi Parasit pada Ikan Manvis, Ikan Black Ghst, Ikan Maskoki, dan Ikan Cupang di Jakarta Timur, DKI Jakarta. [Skrpisi, Unpublished]. Institut Pertanian Bogor.

Ololade, Z. S., Olatunde, O. Z., Oyelese, O. J., Olaoye, O. O. \& Odewande, R. A. (2014). Total Phenolic Content, Free Radical Inhibition, Antioxidan and Antibacterial Potentials of The Medicinal Organic Compounds in The Fruit of Terminalia catappa Linn. Nature and Science. (12) 2: 46-50. https://www.researchgate.net/publication/326752 545_Ololade_ZS_Olatunde_OZ_Oyelese_OJ_Ola oye OO and Odewande RA 2014 Total_Pheno $\underline{\text { lic_Content_Free_Radical_Inhibition_Antioxidan }}$
t_and_Antibacterial_Potentials_of_the_Medicinal _Organic_Compounds_in_the_Fruit

Pal, D., Siddharta, N. J. \& Roy, B. (2007). Immunostimulatory Effect of a Yeast (Saccharomyces cerevisiae) Cell Wall Feed Supplement on Rohu (Labeo rohita), an Indian Major Carp. The Israeli Journal of Aquaculture. 59 (3): 175-181. https://www.semanticscholar.org/paper/Immunost imulatory-Effects-of-a-Yeast-(Saccharo-Cell-PalJoardar/cfc4aa979917ebf83e1ba22ea19ffaca26e3 $\underline{031 f}$

Rudiyanti, S. \& Ekasari, A. D. (2009). Pertumbuhan dan Survival Rate Ikan Mas (Cyprinus carpio Linn) pada Berbagai Konsentrasi Pestisida Regent 0,3 G. Jurnal Saintek Perikanan. 5(1): 39-47. https://core.ac.uk/download/pdf/11718503.pdf

Sembiring R.K. (1995). Analisis Regresi Edisi Kedua. Penerbit ITB. Bandung. https://scholar.google.co.id/scholar?hl=id\&as_sdt $=0 \% 2 \mathrm{C} 5 \& \mathrm{q}=$ Analisis + Regresi+Edisi+Kedua\&bt $\underline{\mathrm{nG}}=$

Setyowati, D. N. (2018). Buku Ajar Parasit dan Penyakit Ikan. Pustaka Bangsa. 222p.

Setyowati, D. N. (2015). Effect of Terminalia cattapa Leaves on The Prevalence and Intensity of Ectoparasites in Nile Tilapia (Oreochromis niloticus). Proceeding of International Seminar on Tropical Natural Resources 2015

Wiroonpan, P. \& Purivirojkul, W. (2019). New Record of Trichodina unionis (Ciliophora, Trichodinidae) from Freshwater Gastropods in Bangkok, Thailand. Parasite. 26 (47):1-11. doi: 10.1051/parasite/2019047. https://www.ncbi.nlm.nih.gov/pubmed/31359860 